\title{
Zastosowanie związków żelaza jako katalizatorów w procesie spalania lekkiego oleju opałowego
}

\begin{abstract}
Przeprowadzono badania skuteczności katalitycznej dwóch organicznych suspensji związków żelaza. Wykonano testy w warunkach rzeczywistych, spalając lekki olej opałowy uszlachetniony badanymi próbkami w kotle o mocy $80 \mathrm{~kW}$. Analizowano skład spalin pod kątem zawartości $\mathrm{CO}, \mathrm{NO}_{x}$, pyłów i niespalonych węglowodorów. Wykazano znaczne różnice w efektywności katalitycznej badanych próbek.
\end{abstract}

Słowa kluczowe: lekki olej opałowy, suspensje związków żelaza, sadza.

\section{Application of iron compounds as catalysts for the oxidation of carbon black in the combustion process of the light heating oil}

Catalytic efficiency of two organic suspensions of iron compounds was tested. Real condition tests were performed by burning light heating oil treated with samples of tested suspensions in $80 \mathrm{~kW}$ power boiler. The exhaust gases were analyzed for $\mathrm{CO}, \mathrm{NO}_{\mathrm{x}}$, dust and unburnt hydrocarbon concentration. Significant differences in the catalytic efficiency of the samples tested were found.

Key words: light heating oil, iron compounds suspension, soot.

\section{Wprowadzenie}

Lekki olej opałowy to paliwo służące do ogrzewania i wytwarzania ciepłej wody użytkowej. Skład komponentowy lekkich olejów opałowych zależny jest od wielu czynników, przede wszystkim od możliwości technologicznych wytwarzającej go rafinerii oraz od typu i jakości rafinowanej ropy naftowej. Paliwo to zawiera zarówno frakcje pochodzące $\mathrm{z}$ atmosferycznej destylacji ropy naftowej, jak również przetworzone frakcje $\mathrm{z}$ destylacji próżniowej. Jego skład oraz właściwości fizykochemiczne i użytkowe zbliżone są do oleju napędowego. Właściwości, jakie ma spełniać lekki olej opałowy, opisane są w normie PN-C-96024 [15].

Aby sprostać obowiązującym wymaganiom jakościowym, lekki olej opałowy mógłby być komponowany z wysokogatunkowych komponentów; wiązałoby się to jednak z wysoką ceną produktu handlowego. Ekonomicznym rozwiązaniem, pozwalającym na sprostanie stawianym wymaganiom, jest poprawa niektórych parametrów jakościowych lekkiego oleju opałowego za pomocą dodatków uszlachetniających. Do tego celu wykorzystywane są głównie dodatki smarnościowe, detergentowo-dyspergujące, przeciwpienne, deemulgujące, biobójcze, przeciwkorozyjne, przeciwutleniające, deaktywatory metali, barwniki i znaczniki.

Wśród wielu zalet stosowania lekkiego oleju opałowego w celach grzewczych wymienić można między innymi: możliwość automatyzacji procesu spalania, możliwość zdalnego załączania i wyłączania kotła, brak konieczności podłączenia do sieci przesyłowej czy niewielkie rozmiary kotła. Nie bez znaczenia jest proekologiczny charakter tego paliwa. Wśród wad należy wskazać dość wysoki koszt wytworzenia $1 \mathrm{kWh}$ ciepła za pomocą tego paliwa, zmienność jego cen oraz problem związany z emisją nanocząstek sadzy. 
Sadza jest substancją sypką, pylistą, składającą się głównie z węgla $(94 \div 99 \%(\mathrm{~m} / \mathrm{m}))$ z niewielkim udziałem wodoru i śladowymi ilościami tlenu, azotu i siarki. Rozmiary cząstek sadzy wahają się w przedziale od $1 \mathrm{~nm}$ do $1000 \mathrm{~nm}$. Z powodu swej rozwiniętej powierzchni absorbuje ona liczne związki organiczne, kwas siarkowy i wodę. $Z$ tego względu sadzę uważa się za substancję niebezpieczną dla zdrowia ludzi i zwierząt $[1,2,9]$.

Emisję sadzy w procesie spalania można ograniczać poprzez zapewnienie w jego trakcie odpowiedniego nadmiaru powietrza. Jednakże ograniczenie jej emisji w fazie rozruchu i wygaszania w ten sposób jest wręcz niemożliwe. Innym sposobem jest stosowanie modyfikatorów spalania, które dzięki swym właściwościom katalitycznym obniżają temperaturę zapłonu sadzy.

Jednym z najczęściej używanych modyfikatorów, tj. katalizatorów spalania sadzy, są substancje zawierające związki metali (głównie tlenki), których elektrony o najwyższej energii znajdują się w stanie podstawowym na orbitalach typu d (metale te mogą występować na wielu stopniach utleniania). Związki zbudowane z pierwiastków tego rodzaju mają zdolność do tworzenia złożonych układów kompleksowych oraz łatwo ulegają reakcjom redoks, co jest szczególnie istotne w przypadku dodatków modyfikujących proces spalania.

Stosowane dotychczas dodatki (do uszlachetniania olejów napędowych) były zbudowane ze związków zawierających głównie metale takie jak: $\mathrm{Ce}, \mathrm{Cu}, \mathrm{Mn}, \mathrm{Fe}, \mathrm{Pt}, \mathrm{Zn}[3-5$, $7,8,10-14]$. Z tej grupy stopniowo eliminuje się mangan ze wzglądu na toksyczność oraz miedź ze względu na jej katalityczne działanie przy tworzeniu dioksyn.

Mechanizm katalitycznego utleniania sadzy jest procesem bardzo złożonym i nie do końca poznanym. Prawdopodobnie w pierwszym etapie reakcji utleniania nanocząsteczki tlenku metalu są absorbowane na powierzchni cząsteczek sadzy. Następnie w temperaturze gazów spalinowych dochodzi do reakcji redoks, przy czym sadza utlenia się do tlenku węgla, a metal redukuje się do swojego niższego stopnia utleniania. Kolejnym etapem jest utlenianie tlenku węgla do ditlenku węgla. Ze względu na niższą stabilność jonów metali na niższych stopniach utleniania, w temperaturze gazów spalinowych następuje szybkie ich utlenienie i powrót do początkowego stopnia utlenienia.

\section{Metodyka badań}

Testy reaktywności w warunkach rzeczywistych wykonano na stanowisku umożliwiającym kontrolę przebiegu procesu spalania. Stanowisko wyposażone było w kocioł olejowy firmy Viessmann, model Paromat Triplex o mocy $80 \mathrm{~kW}$, oraz w aparaturę pomiarową: analizator spalin GA 40T firmy Madur i pyłomierz grawimetryczny P-10ZA firmy ZAM Kęty.

Badania stężeń substancji szkodliwych w spalinach, pochodzących ze spalania lekkiego oleju opałowego, wykonywano w cyklach dwugodzinnych obejmujących dwa etapy. Etap pierwszy - mający na celu rozruch kotła olejowego (osiągnięcie temperatury roboczej instalacji, tj. temperatury kotła wynoszacej $90 \div 95^{\circ} \mathrm{C}$ ), prowadzono przez $30 \mathrm{mi}-$ nut; drugi - właściwy etap - realizowany był przez 90 minut, w czasie jego trwania odczytywano chwilowe stężenia $\mathrm{NO}_{\mathrm{x}}$, $\mathrm{CO}, \mathrm{CH}_{\mathrm{x}} \mathrm{w} 15$-minutowych odstępach $-\mathrm{w}$ sumie 4 pomiary, których średnia była wynikiem końcowym.
Pomiar emisji sadzy - cząstek stałych (PM, Particulate Matter) wykonano według normy PN-Z-04030-7 [16], przy czym zastosowano metodę filtracji wewnętrznej w czasie nie krótszym niż 60 minut i przy objętości próbek spalin w granicach $1 \div 1,3 \mathrm{~m}^{3} /$ godz. Pyły zebrane na filtrze ważono, a następnie wyznaczano stężenie pyłu w gazach wylotowych.

Oznaczenie zawartości $\mathrm{CH}_{\mathrm{x}}$ przeprowadzono przy użyciu metody PN-89/Z-040014 [16], natomiast zawartości CO i $\mathrm{NO}_{\mathrm{x}} \mathrm{w}$ spalinach oznaczono za pomocą metod własnych, w oparciu o działanie sensorów elektrochemicznych i sensorów pracujących na zasadzie absorpcji promieniowania podczerwonego NDIR, wbudowanych w analizator spalin GA 40T. Badania eksploatacyjne wykonano przy współczynniku nadmiaru powietrza $\lambda$ równym $1,05 \div 1,25$, który zapewniał stabilną pracę kotła olejowego.

\section{Charakterystyka zastosowanych lekkich olejów opałowych}

Do przeprowadzenia badań wykorzystano dwa rodzaje paliw scharakteryzowane w tablicach 1 i 2 .

\section{Charakterystyka badanych dodatków}

\section{Dodatek 1}

Dodatek 1, zawierający związki żelaza(III) zdyspergowane za pomocą odpowiednio dobranego dyspergatora w mie- szaninie rozpuszczalników organicznych, otrzymany został według zmodyfikowanej metody Massarta [6]. Zawartość żelaza w tej próbce wynosiła 17,4\% $(\mathrm{m} / \mathrm{m})$. Sposób 
Tablica 1. Właściwości bazowego lekkiego oleju opałowego A

\begin{tabular}{|c|c|c|c|c|}
\hline \multicolumn{2}{|c|}{ Właściwość } & Jednostka & Wyniki badań & Metody badań \\
\hline \multicolumn{2}{|c|}{ Gęstość w temperaturze $15^{\circ} \mathrm{C}$} & {$\left[\mathrm{kg} / \mathrm{m}^{3}\right]$} & 825,5 & $\begin{array}{l}\text { PN-ISO } 3675 \\
\text { PN-EN } 12185\end{array}$ \\
\hline \multicolumn{2}{|l|}{ Wartość opałowa } & {$[\mathrm{MJ} / \mathrm{kg}]$} & 43,2 & PN-86/C-04062 \\
\hline \multicolumn{2}{|c|}{ Temperatura zapłonu } & {$\left[{ }^{\circ} \mathrm{C}\right]$} & 87,5 & PN-EN ISO 2719 \\
\hline \multicolumn{2}{|c|}{ Lepkość kinematyczna w temperaturze $20^{\circ} \mathrm{C}$} & {$\left[\mathrm{mm}^{2} / \mathrm{s}\right]$} & 4,115 & PN-EN ISO 3104 \\
\hline \multicolumn{2}{|c|}{$\begin{array}{l}\text { Skład frakcyjny: } \\
- \text { do } 250^{\circ} \mathrm{C} \\
- \text { do } 350^{\circ} \mathrm{C} \\
\end{array}$} & $\begin{array}{l}{[\%(V / V)]} \\
{[\%(V / V)]}\end{array}$ & $\begin{array}{l}30,5 \\
97,4\end{array}$ & PN-EN ISO 3405 \\
\hline \multicolumn{2}{|c|}{ Temperatura płynięcia } & {$\left[{ }^{\circ} \mathrm{C}\right]$} & -27 & PN-ISO 3016 \\
\hline \multicolumn{2}{|c|}{ Pozostałość po koksowaniu z 10\% pozostałości destylacyjnej } & {$[\%(m / m)]$} & 0,018 & PN-EN ISO 10370 \\
\hline \multirow[t]{2}{*}{ Zawartość siarki } & dla gatunku L-1 & {$[\%(m / m)]$} & - & $\begin{array}{c}\text { PN-ISO } 8754 \\
\text { PN-EN ISO } 14596 \\
\text { ASTM D } 2622 \\
\text { ASTM D } 7039 \\
\end{array}$ \\
\hline & dla gatunku L-0 & {$[\mathrm{mg} / \mathrm{kg}]$} & poniżej 5,0 & $\begin{array}{c}\text { PN-EN ISO } 20884 \\
\text { PN-EN ISO } 20846 \\
\text { ASTM D } 2622\end{array}$ \\
\hline \multicolumn{2}{|c|}{ Zawartość wody } & {$[\mathrm{mg} / \mathrm{kg}]$} & 30 & PN-EN ISO 12937 \\
\hline \multicolumn{2}{|c|}{ Zawartość zanieczyszczeń stałych } & {$[\mathrm{mg} / \mathrm{kg}]$} & 1,4 & PN-EN 12662 \\
\hline \multicolumn{2}{|c|}{ Pozostałość po spopieleniu } & {$[\%(m / m)]$} & 0,002 & PN-EN ISO 6245 \\
\hline \multicolumn{2}{|c|}{ Odporność na utlenienie } & {$\left[\mathrm{g} / \mathrm{m}^{3}\right]$} & 4 & PN-ISO 12205 \\
\hline \multicolumn{2}{|c|}{$\begin{array}{l}\text { Smarność, skorygowana średnica śladu zużycia (WS } 1,4 \text { ) } \\
\text { w temperaturze } 60^{\circ} \mathrm{C}\end{array}$} & {$[\mu \mathrm{m}]$} & 589 & PN-ISO 12156-1 \\
\hline
\end{tabular}

Tablica 2. Właściwości bazowego lekkiego oleju opałowego B

\begin{tabular}{|c|c|c|c|c|}
\hline \multicolumn{2}{|c|}{ Właściwość } & Jednostka & Wyniki badań & Metody badań \\
\hline \multicolumn{2}{|c|}{ Gęstość w temperaturze $15^{\circ} \mathrm{C}$} & {$\left[\mathrm{kg} / \mathrm{m}^{3}\right]$} & 826,0 & $\begin{array}{l}\text { PN-ISO } 3675 \\
\text { PN-EN } 12185\end{array}$ \\
\hline \multicolumn{2}{|l|}{ Wartość opałowa } & {$[\mathrm{MJ} / \mathrm{kg}]$} & 42,9 & PN-86/C-04062 \\
\hline \multicolumn{2}{|c|}{ Temperatura zapłonu } & {$\left[{ }^{\circ} \mathrm{C}\right]$} & 66,0 & PN-EN ISO 2719 \\
\hline \multicolumn{2}{|c|}{ Lepkość kinematyczna w temperaturze $20^{\circ} \mathrm{C}$} & {$\left[\mathrm{mm}^{2} / \mathrm{s}\right]$} & 3,790 & PN-EN ISO 3104 \\
\hline \multicolumn{2}{|c|}{$\begin{array}{l}\text { Skład frakcyjny: } \\
\text { - do } 250^{\circ} \mathrm{C} \\
\text { - do } 350^{\circ} \mathrm{C}\end{array}$} & $\begin{array}{l}{[\%(V / V)]} \\
{[\%(V / V)]}\end{array}$ & $\begin{array}{l}33,6 \\
92,7\end{array}$ & PN-EN ISO 3405 \\
\hline \multicolumn{2}{|c|}{ Temperatura płynięcia } & {$\left[{ }^{\circ} \mathrm{C}\right]$} & -4 & PN-ISO 3016 \\
\hline \multicolumn{2}{|c|}{ Pozostałość po koksowaniu z 10\% pozostałości destylacyjnej } & {$[\%(m / m)]$} & 0,017 & PN-EN ISO 10370 \\
\hline \multirow{2}{*}{ Zawartość siarki } & dla gatunku L-1 & {$[\%(m / m)]$} & - & $\begin{array}{c}\text { PN-ISO } 8754 \\
\text { PN-EN ISO } 14596 \\
\text { ASTM D } 2622 \\
\text { ASTM D } 7039\end{array}$ \\
\hline & dla gatunku L-0 & {$[\mathrm{mg} / \mathrm{kg}]$} & poniżej 5,0 & $\begin{array}{c}\text { PN-EN ISO } 20884 \\
\text { PN-EN ISO } 20846 \\
\text { ASTM D } 2622 \\
\text { ASTM D } 7039\end{array}$ \\
\hline \multicolumn{2}{|l|}{ Zawartość wody } & {$[\mathrm{mg} / \mathrm{kg}]$} & 30 & PN-EN ISO 12937 \\
\hline \multicolumn{2}{|c|}{ Zawartość zanieczyszczeń stałych } & {$[\mathrm{mg} / \mathrm{kg}]$} & 3,2 & PN-EN 12662 \\
\hline \multicolumn{2}{|c|}{ Pozostałość po spopieleniu } & {$[\%(m / m)]$} & 0,0006 & PN-EN ISO 6245 \\
\hline \multicolumn{2}{|c|}{ Odporność na utlenienie } & {$\left[\mathrm{g} / \mathrm{m}^{3}\right]$} & 4 & PN-ISO 12205 \\
\hline \multicolumn{2}{|c|}{$\begin{array}{l}\text { Smarność, skorygowana średnica śladu zużycia (WS } 1,4) \\
\text { w temperaturze } 60^{\circ} \mathrm{C}\end{array}$} & {$[\mu \mathrm{m}]$} & 590 & PN-ISO 12156-1 \\
\hline
\end{tabular}


otrzymywania tego dodatku jest chroniony zgłoszeniami patentowymi RP na rzecz INiG - PIB (numery zgłoszeń: P.414929 i P.414937). Dodatek jest stabilny w trakcie magazynowania i jest rozpuszczalny w lekkim oleju opałowym w sposób nieograniczony.

\section{Dodatek 2}

Dodatek 2 to produkt handlowy, który według specyfikacji producenta zawierał związki żelaza(III) zdyspergowane w organicznym rozpuszczalniku. Całkowita zawartość żelaza w tej próbce wynosiła 15,0\% $(\mathrm{m} / \mathrm{m})$.

\section{Wyniki badań}

Przeprowadzono badania wielkości emisji szkodliwych składników spalin pochodzących ze spalania bazowych lekkich olejów według przedstawionej metodyki. Zbadano emisję związaną ze spalaniem dwóch bazowych lekkich olejów opałowych. Wyniki badań wraz z obliczonymi wartościami średnimi, odchyleniami standardowymi oraz przeliczeniami na emisję godzinową poszczególnych składników zamieszczono w tablicach 3 i 4 .

Bazowe lekkie oleje opałowe A i B uszlachetniono badanymi dodatkami w takiej ilości, by stężenie żelaza w paliwie wynosiło $20 \mathrm{mg} / \mathrm{kg}$. Przeprowadzono badania wielkości emisji szkodliwych składników spalin pochodzących ze spalania uszlachetnionych lekkich olejów według przedstawionej metodyki, a uzyskane wyniki przedstawiono na rysunkach 1-4.

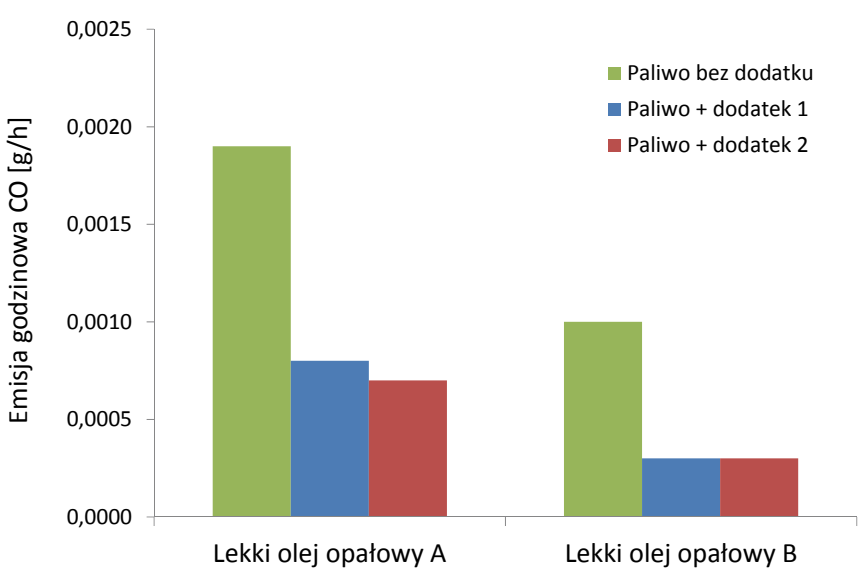

Rys. 1. Porównanie emisji godzinowej CO pochodzącej ze spalania lekkich olejów opałowych A i B uszlachetnionych badanymi dodatkami
Tablica 3. Wartości emisji wybranych składników pochodzące ze spalania bazowego lekkiego oleju opałowego A

\begin{tabular}{|c|c|c|c|c|}
\hline \multirow{2}{*}{$\begin{array}{c}\text { Bazowy lekki } \\
\text { olej opałowy A }\end{array}$} & \multicolumn{4}{|c|}{ Stężenie } \\
\hline & $\begin{array}{c}\mathrm{CO} \\
{\left[\mathrm{mg} / \mathrm{Nm}^{3}\right]}\end{array}$ & $\begin{array}{c}\mathrm{NO}_{\mathrm{x}} \\
{\left[\mathrm{mg} / \mathrm{Nm}^{3}\right]}\end{array}$ & $\begin{array}{c}\mathrm{CH}_{\mathrm{x}} \\
{[\%(V / V)]}\end{array}$ & $\begin{array}{c}\mathrm{PM} \\
{\left[\mathrm{mg} / \mathrm{Nm}^{3}\right]}\end{array}$ \\
\hline Wyniki pomiarów & $\begin{array}{l}0,010 \\
0,009 \\
0,011 \\
0,008 \\
0,011\end{array}$ & $\begin{array}{l}0,084 \\
0,086 \\
0,086 \\
0,086 \\
0,086\end{array}$ & $\begin{array}{l}0,30 \\
0,20 \\
0,30 \\
0,20 \\
0,30\end{array}$ & 0,0070 \\
\hline Średnia & 0,010 & 0,086 & 0,26 & 0,0070 \\
\hline Odchylenie standardowe & 0,001 & 0,001 & 0,05 & - \\
\hline Emisja godzinowa $[\mathrm{g} / \mathrm{h}]$ & 0,002 & 0,016 & - & 0,0013 \\
\hline
\end{tabular}

Tablica 4. Wartości emisji wybranych składników pochodzące ze spalania bazowego lekkiego oleju opałowego B

\begin{tabular}{|l|c|c|c|c|}
\hline \multirow{2}{*}{\begin{tabular}{c}
\multirow{2}{*}{$\begin{array}{c}\text { Bazowy lekki } \\
\text { olej opałowy B }\end{array}$} \\
\cline { 2 - 5 }
\end{tabular}} & $\begin{array}{c}\mathrm{CO} \\
{\left[\mathrm{mg} / \mathrm{Nm}^{3}\right]}\end{array}$ & $\begin{array}{c}\mathrm{NO}_{\mathrm{x}} \\
{\left[\mathrm{mg} / \mathrm{Nm}^{3}\right]}\end{array}$ & $\begin{array}{c}\mathrm{CH}_{\mathrm{x}} \\
{[\%(V / V)]}\end{array}$ & $\begin{array}{c}\mathrm{PM} \\
{\left[\mathrm{mg} / \mathrm{Nm}^{3}\right]}\end{array}$ \\
\hline \multirow{3}{*}{ Wyniki pomiarów } & 0,006 & 0,072 & 0,200 & \\
& 0,006 & 0,071 & 0,200 & 0,006 \\
& 0,006 & 0,075 & 0,200 & \\
\hline Średnia & 0,006 & 0,073 & 0,200 & 0,006 \\
\hline Odchylenie standardowe & 0,007 & 0,076 & 0,300 & - \\
\hline Emisja godzinowa $[\mathrm{g} / \mathrm{h}]$ & 0,006 & 0,073 & 0,220 & 0,001 \\
\hline
\end{tabular}

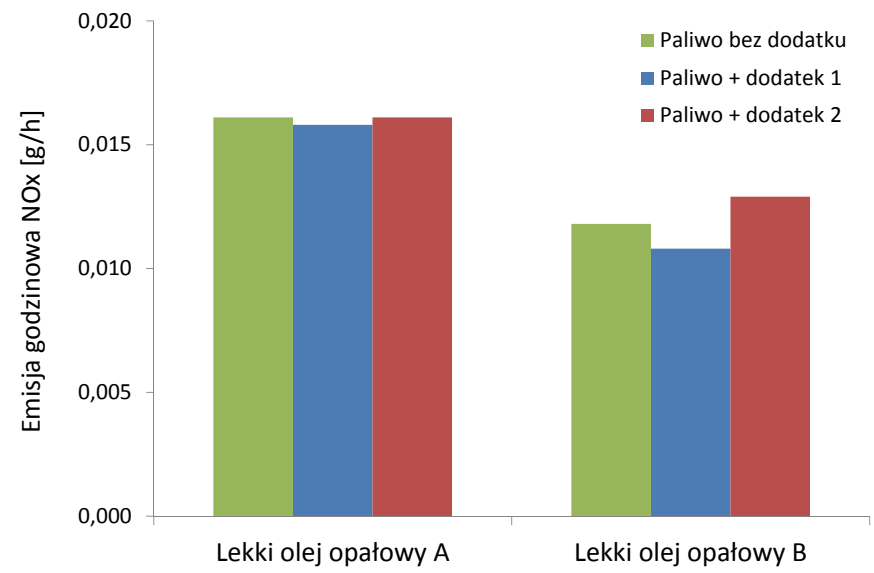

Rys. 2. Porównanie emisji godzinowej $\mathrm{NO}_{x}$ pochodzącej ze spalania lekkich olejów opałowych A i B uszlachetnionych badanymi dodatkami 


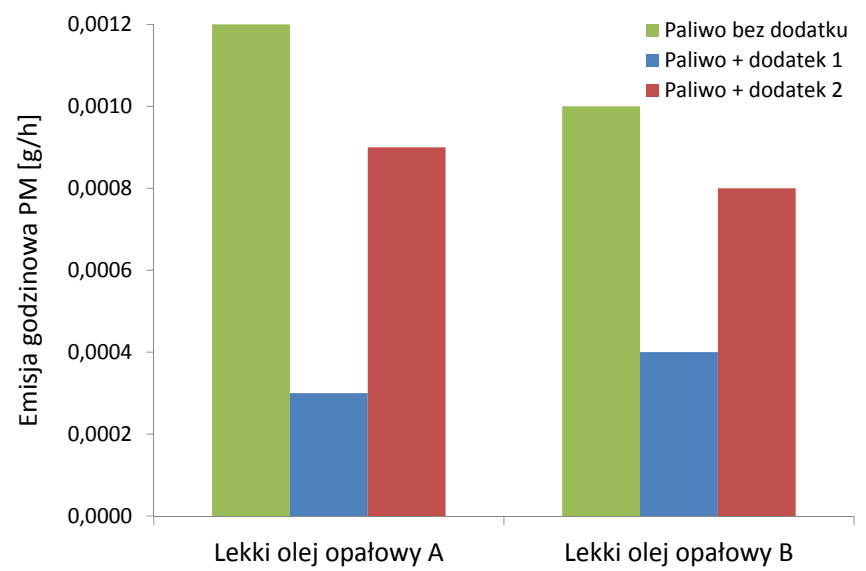

Rys. 3. Porównanie emisji godzinowej PM pochodzącej ze spalania lekkich olejów opałowych A i B uszlachetnionych badanymi dodatkami

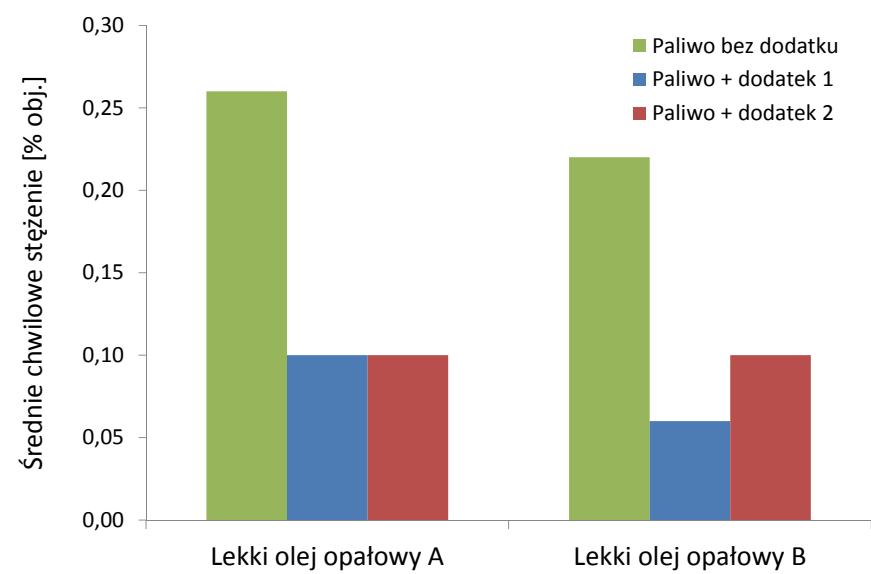

Rys. 4. Emisja $\mathrm{CH}_{x}$ pochodząca ze spalania lekkich olejów opałowych A i B zawierających badane dodatki

\section{Omówienie wyników}

Na podstawie przeprowadzonych badań stwierdzono, że emisja ze spalania bazowego lekkiego oleju opałowego B we wszystkich grupach zanieczyszczeń była niższa niż w przypadku emisji pochodzącej ze spalania testowego bazowego lekkiego oleju opałowego A.

Różnice oznaczonych poziomów emisji były znaczne. Emisja całkowita $\mathrm{CO}$ pochodzaca ze spalania lekkiego oleju opałowego B była o około 47\% niższa niż w przypadku paliwa A, emisja tlenków azotu - o około $27 \%$, natomiast emisja sadzy była niższa aż o $54 \%$.

Średnie chwilowe stężenie niespalonych węglowodorów w spalinach pochodzących ze spalania lekkiego oleju opałowego A było wyższe o $18 \%$ niż w przypadku tego samego parametru dla lekkiego oleju opałowego B.

Znaczne różnice w zawartości szkodliwych substancji obecnych w gazach spalinowych pochodzących od badanych paliw najprawdopodobniej wynikają $\mathrm{z}$ ich różnego składu frakcyjnego. Lekki olej opałowy B zawiera więcej lekkich frakcji.

Po uszlachetnieniu paliw badanymi dodatkami 1 i 2 ilość toksycznych składników spalin obniżyła się we wszystkich przypadkach. Przy paliwie A dodatek 1 wykazał nieznacznie słabszą aktywność w obniżeniu zawartości CO niż dodatek 2, natomiast zaobserwowano wyższą efektywność dodatku $1 \mathrm{w}$ przypadku obniżania emisji $\mathrm{NO}_{\mathrm{x}}$ oraz dużo wyższą skuteczność (około trzykrotnie) w ograniczaniu emisji pyłów. Efektywność obniżania emisji niespalonych węglowodorów w wypadku obu badanych próbek była jednakowa.

W przypadku paliwa B dodatki 1 i 2 wykazały jednakową skuteczność w obniżaniu emisji $\mathrm{CO}$, natomiast w sytuacji emisji $\mathrm{NO}_{x}$, pyłów i niespalonych węglowodorów dodatek 1 wykazał wyższą skuteczność w obniżaniu ich zawartości.

Przyczynami znacznych różnic w skuteczności działania związków żelaza jako katalizatorów utleniania sadzy, jak również obniżania innych szkodliwych składników spalin (pomimo stosowania ich w tym samym stężeniu) mogą być:

- różnice stabilności badanych suspensji; niestabilny dodatek może wytrącać się z lekkiego oleju opałowego, co powoduje zmniejszenie jego efektywnego stężenia w paliwie; - różnice w strukturze związków żelaza; odmiana fazowa może mieć znaczny wpływ na efektywność działania katalitycznego.

Prosimy cytować jako: Nafta-Gaz 2017, nr 9, s. 635-640, DOI: 10.18668/NG.2017.09.02

Artykuł nadesłano do Redakcji 26.06.2017 r. Zatwierdzono do druku 31.07.2017 r.

Artykuł powstał w ramach projektu PBS współfinansowanego z NCBiR pt.: Opracowanie wielofunkcyjnego pakietu dodatków zawierajacego innowacyjny modyfikator procesu spalania typu FBC (Fuel Born Catalyst) do lekkiego oleju opałowego; nr umowy PBS1/B1/4/2012.

\section{Literatura}

[1] Dai Y., Niu Y., Duan H.: Effects of occupational exposure to carbon black on peripheral white blood cell counts and lymphocyte subsets. Environmental and Molecular Mutagenesis 2016, vol. 57, nr 8, s. 615-622.
[2] Gao X., Shang J., Yang J.: Comparison of genetic damage in mice exposed to black carbon and ozone-oxidized black carbon. Journal of Peking University. Health Sciences 2014, vol. 46, nr 3, s. 400-404. 
[3] Kim K., Hahn D.W.: Interaction between iron based compound and soot particles in diffusion flame. Energy 2016, vol. 116, s. 933-941.

[4] Legutko P., Jakubek T., Kaspera W., Stelmachowski P., Sojka Z., Kotarba A.: Soot oxidation over K-doped manganese and iron spinels - how potassium precursor nature and doping level changes the catalysts activity. Catalysis Communications 2014, vol. 43, s. 34-37.

[5] Li H., Li K., Wang H., Zhu X., Wei Y., Yan D., Cheng X., Zhai K.: Soot combustion over $\mathrm{Ce}_{1-x} \mathrm{Fe}_{x} \mathrm{O}_{2-\delta}$ and $\mathrm{CeO} / \mathrm{Fe}_{2} \mathrm{O}_{3}$ catalysts: Roles of solid solution and interfacial interactions in the mixed oxides. Applied Surface Science 2016, vol. 390, s. 513-525.

[6] Massart R.: Preparation of aqueous magnetic liquids in alkaline and acidic media. IEEE Trans Magn. 1981, vol. 17, s. $1247-2148$.

[7] Matarrese R., Morandi S., Castoldi L., Villa P., Lietti L.: Removal of $\mathrm{NO}_{x}$ and soot over $\mathrm{Ce} / \mathrm{Zr} / \mathrm{K} / \mathrm{Me}(\mathrm{Me}=\mathrm{Fe}, \mathrm{Pt}$, $R u, A u)$ oxide catalysts. Applied Catalysis B: Environmental 2017, vol. 201, s. 318-330.

[8] Mukherjee D., Govinda Rao B., Reddy B.M.: CO and soot oxidation activity of doped ceria: Influence of dopants. Applied Catalysis B: Environmental 2016, vol. 197, s. 105-115.

[9] Niranjan R., Thakur A.K.: The toxicological mechanisms of environmental soot (black carbon) and carbon black: Focus on Oxidative stress and inflammatory pathways. Frontiers in Immunology 2017, vol. 8, s. 763.

[10] Stępień Z., Żak G., Łukasik Z.: Dodatki FBC do oleju napędowego wspomagajace regeneracje filtrów czątek statych. Nafta-Gaz 2009, nr 11, s. 861-870.

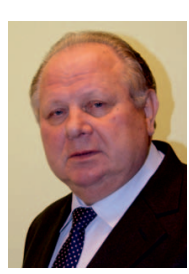

Prof. dr hab. inż. Janusz JAKÓBIEC

Profesor zwyczajny

Wydział Energetyki i Paliw,

Katedra Technologii Paliw

Akademia Górniczo-Hutnicza

al. Mickiewicza 30, 30-059 Kraków

E-mail:jjakobie@agh.edu.pl
[11] Sungur B., Topaloglu B., Ozcan H.: Effects of nanoparticle additives to diesel on the combustion performance and emissions of a flame tube boiler. Energy 2016, vol. 113, s. 44-51.

[12] Żak G., Wojtasik M.: Nanodyspersje metaloorganiczne FBC (Fuel Borne Catalyst) jako efektywne katalizatory utleniania sadzy na filtrach gazów spalinowych. Nafta-Gaz 2009, nr 10, s. 797-804.

\section{Akty prawne i normatywne}

[13] Patent USA 4998876 Combustion of liquid hydrocarbons, 1991.

[14] Patent USA 5944858 Hydrocarbonaceous fuel compositions and additives therefor, 1999

[15] PN-C-96024:10 Produkty naftowe. Oleje opałowe, 2011.

[16] PN-Z-04030-7 Badanie zawartości pytu - Pomiar stężenia $i$ zawartości masy pyłu w gazach odlotowych metoda grawimetryczna, 2007.

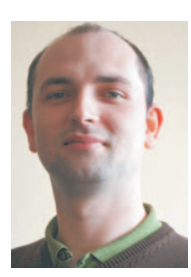

Dr Michał WOJTASIK

Asystent w Zakładzie Dodatków i Nowych

Technologii Chemicznych.

Instytut Nafty i Gazu - Państwowy Instytut Badawczy ul. Lubicz 25 A

31-503 Kraków

E-mail: michal.wojtasik@inig.pl

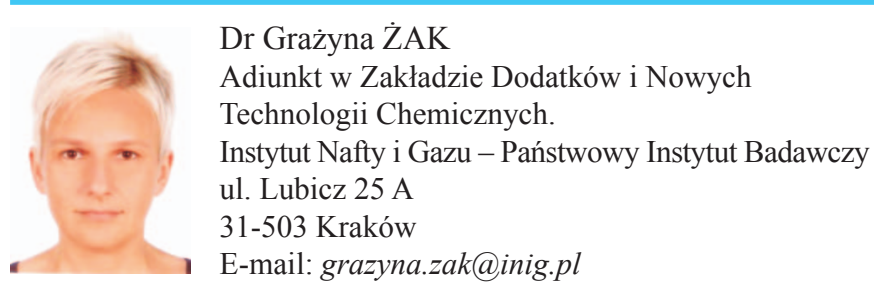

